\title{
Pengaruh Hypnopressure terhadap Produksi Air Susu Ibu (ASI) dan Kepercayaan Diri Menyusui
}

\author{
Diah Evawanna Anuhgera ${ }^{1, *}$, Elsaria Sembiring ${ }^{2}$ \\ ${ }^{1}$ Program Studi Kebidanan Program Sarjana, Fakultas Kebidanan, Institut Kesehatan Medistra Lubuk Pakam, 20512, Indonesia \\ ${ }^{2}$ Program Studi Fisioterapi, Fakultas Keperawatan dan Fisioterapi, Institut Kesehatan Medistra Lubuk Pakam , 20512, Indonesia \\ ${ }^{1}$ diah.evawanna@gmail.com*; ${ }^{2}$ elsariasembiring21@ gmail.com \\ * corresponding author
}

ARTICLE INFO

Article history

25-08-2021

$16-09-2021$

04-10-2021

Keywords

Hypnopressure

Kepercayaan diri

Menyusui

\section{ABSTRACT}

Breastfeeding is an obligation that must be given to babies during their growth period. Consistent breast milk production and confidence to breastfeed are very necessary for the success of exclusive breastfeeding. Hypnopressure is one method that can increaseand maintain breastmilk production and breastfeeding confidence. The purpose of this project is to analyze the effect of hypnopressure on breast milk production and breastfeeding confidence. This study uses Quasy Eksperimental with Pretest dan Posttest Controlled Group Design. There were 28 postpartum mothers who were divided into two groups and taken with simple random sampling. Production of breast milk was measured by electric breast pump and breastfeeding sel efficacy was measured Breastfeeding Self Efficacy Scale (BSES). Data were analyzed using paired and unpaired t-test. Primary outcomes of this study will be effect of the intervention on breastmilk production and breastfeeding confidence. We conclude that hypnopressure could improve breastmilk production $(\mathrm{p}=0.00)$ and breasfeeding confidence $(\mathrm{p}=0.00)$ and breastfeeding confidence $(\mathrm{p}=0.00)$. Result of this greater understanding about increase breast milk production and confidence which influence the success of breastfeeding by hypnopressure then be useful targets for midwife intervention in post partum.

\section{Pendahuluan}

Masa bayi awal merupakan masa kritis perkembangan dan pertumbuhan di mana nutrisi memiliki dampak penting pada jangka panjang kesehatan dan pembangunan [1]. Menyusui adalah standar nutrisi yang terbaik bag bayi dan memberikan manfaat kesehatan jangka penden dan panjang bagi bayi dan ibu [2]. Victora CG et al, 2016 menyatakan bahwa peningkatkan pemberian ASI (Air Susu Ibu) di seluruh dunia hingga 50\% dapat menyelamatkan kehidupan $>800.000$ bayi dan anak, dan mencegah $>20.000$ ibu kematian akibat kanker payudara setiap tahun, serta mengurangi ketimpangan sosial ekonomi. Keyakinan menyusui secara global sangat rendah dan hampir kurang dari setengah populasi ibu menyusui di dunia tidak eksklusif dalam memberikan ASI selama 6 bulan pertama di masa kehidupan bayi [2][3]. Di daerah pedesaan Cina, tingkat pemberian ASI Eksklusif untuk bayi dalam enam bulan pertama hanya 28,7\% [4].

Selain faktor sosial ekonomi dan budaya yang dapat mempengaruhi keputusan ibu untuk menyusui. Kinerja laktasi juga dipengaruhi oleh ibu kondisi fisiologis dan psikologis, serta faktor perilaku bayi [5]. Kepercayaan diri menyusui adalah salah satu poin utama dalam mensuksesksan proses menyusui yang eksklusif. Dengan kepercayaan diri yang baik maka ibu akan berusaha memberikan ASI yang terbaik kepada bayinya. Aspek psikososial yang berhubungan dengan produksi ASI dan kepercayaan diri menyusui kurang di eksplorasi oleh para ibu, walaupun menyusui adalah proses dinamis yang melibatkan sinyal kompleks dan perilaku negosiasi antara ibu dan bayi [5][6]. Emosi ibu pada proses menyusui memiliki hubungan dengan produksi ASI dan peningkatan saliva yang berhubungan dengan adanya peningkatan kadar hormon kortisol dan hal 
tersebut tidak ditemukan pada susu formula [7]. Kortisol plasma ibu memiliki korelasi dengan gangguan psikologis dan kesulitan proses menyusui selama periode postpartum, dan sangat berpengaruh dengan produksi ASI [8].

Di era pandemi COVID-19 banyak para ibu yang lebih merasa khawatir akan kesehatan nya dan bayinya termasuk pada pemberian ASI eksklusif. Hasil penelitian terbaru COVID-19 di Inggris menunjukkan adanya peningkatan rasa cemas, takut pada ibu hamil, bersalin dan menyusui di era pandemic COVID-19. Hal tersebut juga terjadi pada Turki yang menunjukkan terjadi peningkatan depresi post partum sebesar 34 persen [9][10]. Ketakutan dapat mempengaruhi keyakinan pada pemberian ASI dan menentukan kesehatan ibu dan bayi, baik jangka pendek maupun jangka panjang.

Hasil penelitian Kruth E (2011) bahwa adanya korelasi positif antara kadar kortisol plasma ibu dengan kortisol ASI. Hal ini menunjukkan bahwa kadar kortisol dari plasma ibu di transfer ke air susu [13]. Sebaliknya, tangisan bayi yang terus menerus memiliki hubungan dengan depresi pada ibu [13]. Faktor ibu dan bayi sangat erat kaitannya dalam menentukan kesuksesan pemberian ASI.Produksi ASI dipengaruhi juga oleh waktu pengambilan ASI, strategi peningkatan ASI yang dilakukan, dan tahapan laktasi [11].

Upaya yang efektif dan sederhana dapat diterapkan untuk meningkatkan kesehatan dan kelangsungan hidup bayi baru lahir adalah menyusui segera setelah melahirkan yaitu inisiasi menyusui dini (IMD), dan pemberian ASI eksklusif. Konsistensi dari produksi ASI yang lancar akan meningkatkan kenyaman dalam menyusui dan memenuhi kebutuhan nutrisi bayi [12]. Kombinasi terapi hipnoterapi dan akupresur atau hypnopressure merupakan intervensi yang secara holistik dapat dilakukan untuk mengatasi masalah ketidakpercayaan diri pada menyusui dan produksi ASI.Intervensi ini memperhatikan tubuh, pikiran dan jiwa. Pelaksanaan ilmu kesehatan secara holistik harus memperhatikan aspek psikoneuro, endokrin dan imuno karena ketidakseimbangan antara pikiran dan jiwa akan mengakibatkan gangguan keseimbangan antara sistem saraf, hormon dan kekebalan tubuh [13].

Hypnopressure dapat membantu ibu untuk memastikan bahwa ibu menyusui dapat terus memberikan ASI, setidaknya secara eksklusif selama enam bulan pertama, terutama jika ibu menyusui harus kembali bekerja. Dukungan untuk menyusui di Indonesia dirasa masih kurang, oleh karena itu ibu menyusui harus selalu berusaha menciptakan kondisi positif baginya untuk terus bisa menyusui. Hypnopressure merupakan teknik relaksasi untuk membantu kelancaran proses menyusui. Cara memasukkan afirmasi positif yang membantu proses menyusui saat ibu sedang santai atau sangat berkonsentrasi pada sesuatu. Dasar hypnopressure adalah relaksasi yang dicapai ketika tubuh dan jiwa dalam kondisi tenang [14].

Sebuah tinjauan sistematis melaporkan bahwa hypnopressure selama menyusui dapat bermanfaat bagi ibu dan meningkatkan kepercayaan diri menyusui sehingga mengurangi stres ibu dan meningkatkan volume ASI [15]. Pada Esfahani et al, 2015 dalam sebuah penelitian tentang adanya pengaruh akupunktur pada menyusui ibu dengan meningkatkan sekresi hormon prolaktin. Penelitian Rahayu D tentang peningkatan produksi ASI melalui penekanan titik akupresur, hasilnya menunjukkan bahwa akupresur bersama pijat laktasi efektif pada produksi dan pengeluaran ASI [17].

Tujuan dari penelitian ini adalah untuk mengetahui adanya pengaruh pemberian hypnopressure terhadap produksi ASI dan kepercayan diri pada proses menyusui. Hal ini bertujuan untuk mengurangi tekanan ibu dengan mempromosikan relaksasi melalui Hypnopressure selama menyusui melalui penggunaan terapi relaksasi dan akupressure dalam uji coba terkontrol secara acak.

\section{Metode}

Penelitian ini merupakan penelitian ekspremintal observasional dengan pendekatan esperimen semu. Design penelitian yang digunakan pretest-posttest controlled group design. Penelitian dilakukan mulai 04 April-18 Agustus 2021 di Klinik Dini Lubuk Pakam Kabupaten Deli Serdang. Sampel penelitian ini adalah seluruh ibu nifas post partum hari pertama yang sesuai dengan kriteria inklusi dan eksklusi. Subjek pada penelitian ini dikumpulkan dengan teknik simple 
random sampling dengan jumlah 28 responden dan dibagi menjadi dua kelompok 14 ibu dimasukan ke dalam kelompok intervensi dan 14 lainnya dimasukkan ke dalam kelompok kontrol. Kelompok intervensi akan diberikan hypnopressure (hypnosis dan acupressure). Kelompok kontrol diberikan standar asuhan kebidanan post partum normal.

Kriteria inklusi dalam penelitian ini adalah ibu nifas pada hari pertama post partum, ibu primigravida dan multigravida tanpa komplikasi pada ibu dan bayi, tidak mengkonsumsi boster ASI, tidak memiliki kelainan putting, tidak mengalami gangguan pernapasan. Penelitian ini dilakukan selama 7 hari dimulai pada hari kedua post partum hingga hari ke 8 post partum. Pada kelompok intervensi dilakukan hypnopressure selama 40 menit.Kedua intervensi diberikan 1 kali sehari sebanyak 7 kali tindakan selama 7 hari.Pada hari ke 8 dilakukan pengukuran produksi ASI dan kepercayaan diri ibu setelah dilakukan intervensi. Pengumpulan data dilakukan dengan melakukan pengukuran terhadap produksi ASI pada hari pertama post partum dengan menggunakan pompa asi elektrik dan menyebarkan kuesioner Breastfeeding Self Efficacy Scale (BSES) Short Form untuk menilai kepercayaan diri menyusui sebelum diberikan intervensi.

Variabel produksi ASI diukur dengan menggunakan pompa asi elektrik untuk menilai jumlah ASI yang dihasilkan selama pemberian intervensi sedangkan variabel kepercayaan diri menyusui diukur dengan menggunakan kuesioner Breastfeeding Self Efficacy Scale (BSES) Short Form yang telah diakui validitas dan rehabilitasnya. Analisa data menggunakan uji t independen dan uji t dependen.

Penelitian ini telah lulus uji etik dari Komite Etik Fakultas Keperawatan Universitas Sumatera Utara dengan nomor 2300/VI/SP/2021.

\section{Hasil dan Diskusi}

Tabel 1. Karakteristik Responden Pada Kelompok Kontrol dan Intervensi

\begin{tabular}{|c|c|c|c|c|}
\hline \multirow{3}{*}{$\begin{array}{l}\text { Karakteristik } \\
\text { Responden }\end{array}$} & \multicolumn{4}{|c|}{ Kelompok } \\
\hline & \multicolumn{2}{|c|}{ Intervensi (Hypnopressure) } & \multicolumn{2}{|c|}{ Kontrol } \\
\hline & $\mathrm{n}$ & $\%$ & $\mathrm{n}$ & $\%$ \\
\hline \multicolumn{5}{|l|}{ Usia } \\
\hline$<20$ tahun & 3 & 21.42 & 2 & 14.28 \\
\hline 20-35 tahun & 5 & 35.71 & 7 & 50 \\
\hline$>35$ tahun & 6 & 42.85 & 5 & 35.71 \\
\hline \multicolumn{5}{|l|}{ Pendidikan } \\
\hline SD & 0 & 0 & 1 & 7.14 \\
\hline SMP & 2 & 14.28 & 4 & 21.42 \\
\hline SMA & 8 & 57.14 & 7 & 50 \\
\hline PT & 4 & 28.57 & 3 & 21.42 \\
\hline \multicolumn{5}{|l|}{ Pekerjaan } \\
\hline Bekerja & 5 & 35.71 & 6 & 42.85 \\
\hline Tidak Bekerja & 9 & 64.28 & 8 & 57.14 \\
\hline \multicolumn{5}{|c|}{ Jumlah persalinan } \\
\hline Primigravida & 9 & 64.28 & 10 & 71.42 \\
\hline Multigravida & 5 & 35.71 & 4 & 21.42 \\
\hline \multicolumn{5}{|l|}{ IMT } \\
\hline$<18.5$ & 2 & 14.28 & 1 & 7.14 \\
\hline $17-22.9$ & 6 & 42.85 & 7 & 50 \\
\hline$>23$ & 6 & 42.85 & 6 & 42.85 \\
\hline
\end{tabular}

Tabel 1 menunjukkan bahwa sebagian besar ibu nifas berusia 20-35 tahun sebanyak 12 responden, sebagian besar berpendidikan SMA sebanyak 15 responden, sebagian besar ibu tidak bekerja sebanyak 17 responden dan sebagian besar ibu primigravida sebanyak 19 responden, Tidak terdapat perbedaan rerata usia dan indeks masa tubuh antara kelompok kontrol dan intervensi (Tabel 1). 
Hasil penelitian ini sejalan dengan Rahayu (2015) menunjukkan rerata karakterisitik umur 26-35 tahun responden pada kelompok perlakuan dan kontrol paling banyak sebesar 62,5\% [17]. Hasil penelitian ini diperkuat oleh hasil penelitian Bryan R.A (2013) menyatakan bahwa ibu yang berusia 20-35 tahun mengalami kenaikan kadar hormon prolaktin dan produksi ASI yang lebih tinggi dari rata-rata dibandingkan ibu yang berusia >35 tahun.Usia merupakan faktor tidak langsung yang mempengaruhi produksi ASI. Usia reproduksi < 35 tahun merupakan usia terbaik untuk menghasilkan produksi ASI yang lebih banyak dibandingankan ibu yang sudah tua [20].

Penelitian ini sejalan dengan penelitian yang dilakukan oleh $\mathrm{Ku}, \mathrm{C}(2010)$ yangmenyatakan tidak ada hubungan antara paritas dengan praktik menyusui pada ibu post partum normal. Informasi menyusui pada ibu nifas diperkirakan mempengaruhi pada proses menyusui [6].

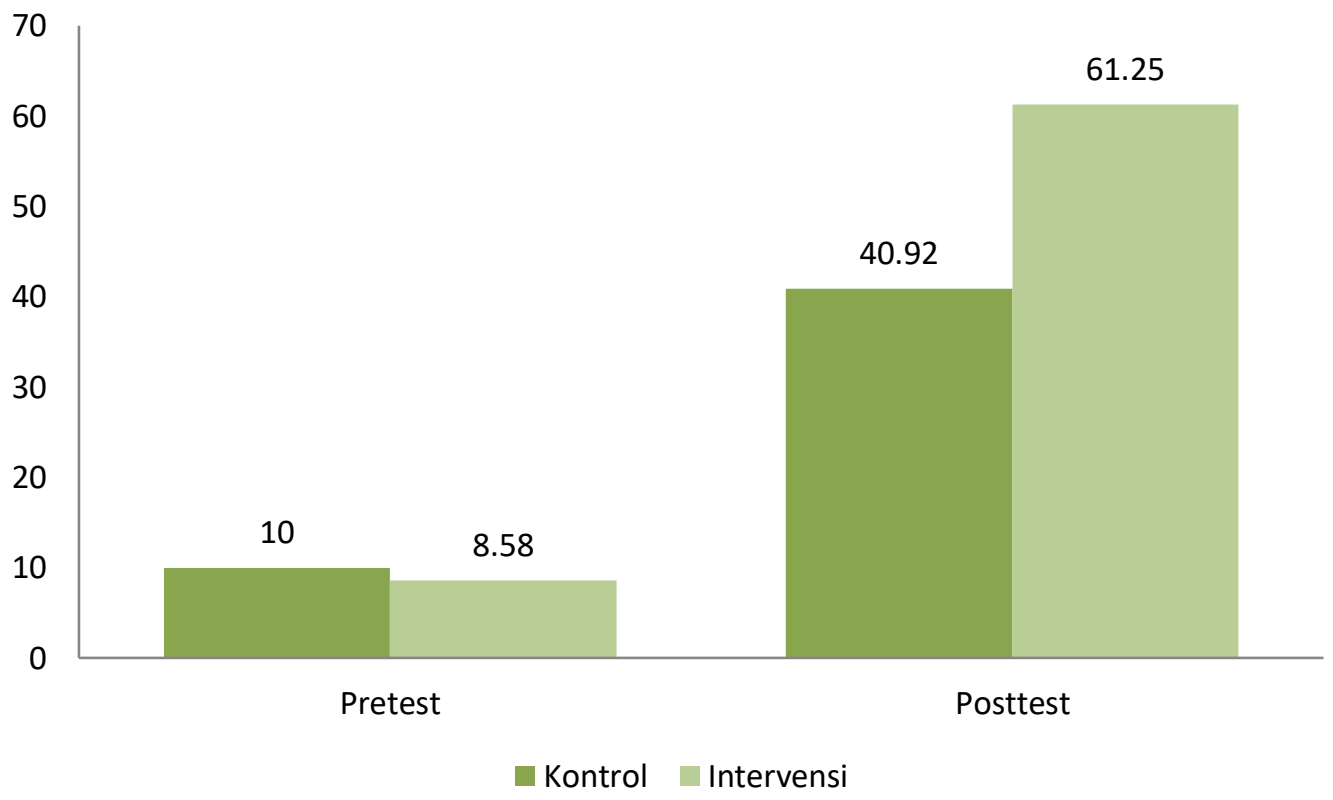

\section{Gambar 1. Rerata Produksi ASI Sebelum dan Sesudah pada Kelompok Kontrol dan Intervensi}

Gambar 1 menunjukkan bahwa ada perbedaan yang signifikan pada rerata produksi ASI sebelum dan sesudah intervensi $(\mathrm{p}=0.00)$ pada kelompok kontrol dengan perbedaan mean 30.91 \pm 12.71. Dan terdapat perbedaan yang signifikan rerata produksi ASI sebelum dan sesudah pada kelompok intervensi (pemberian hypnopressure) dengan perbedaan mean 52.66 \pm 11.71 dan nilai $\mathrm{p}=0.00$. Pada penelitian ini menyimpulkan bahwa ada pengaruh hypnopressure terhadap produksi ASI antara kelompok intervensi dan kontrol dengan nilai $\mathrm{p}=0.00$ (Gambar 1). 


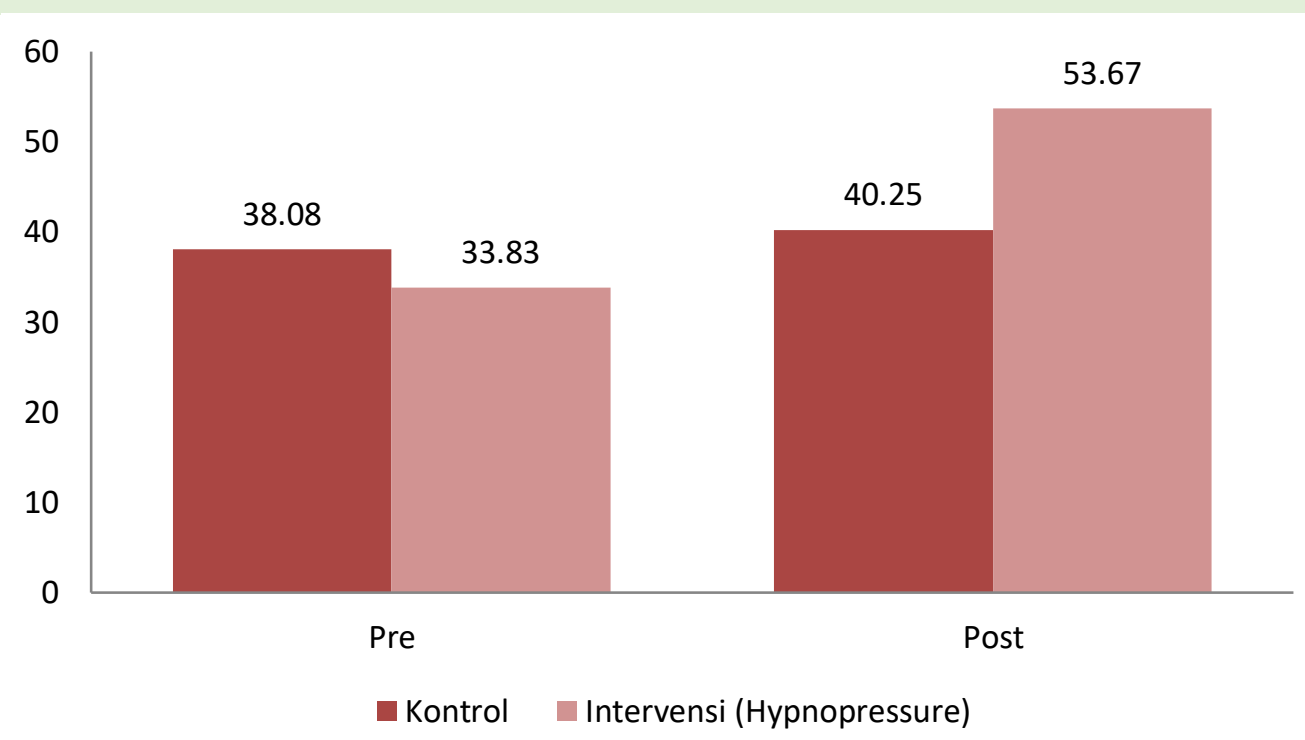

Gambar 1. Kepercayaan Diri Menyusui Sebelum dan Sesudah pada Kelompok Kontrol dan Intervensi

Kepercayaan diri menyusui meningkat secara signifikan sebelum dan sesudah terapi pada kelompok intervensi dengan nilai $\mathrm{p}=0.00$ dan perbedaan mean sebesar $19.83 \pm 8.37$, namun tidak terdapat perbedaan skor kepercayaan menyusui pada kelomok kontrol (Gambar 2). Terdapat perbedaan yang signifikan pada rerata skor kepercayaan diri menyusui antara kelompok kelompok intervensi dengan pemberian hypnopressure dan kelompok kontrol dengan nilai $\mathrm{p}=0.00$. Hal ini sejalan dengan hasil penelitian Shukri et al (2019) bahwa pemberian hipnoterapi dan akupresur dapat mempengaruhi perilaku menyusui dan volume ASI serta penurunan hormone kortisol dimana terjadi penurunan hormone stress pada kelompok intervensi sehingga ibu dapat memberikan ASI dengan rileks, nyaman dan menghasilkan ASI yang berkualitas bagi bayinya [23].

\section{Pembahasan}

Produksi ASI pada wanita dengan kelompok intervensi lebih tinggi dari kelompok kontrol karena dengan intervensi hypnopressure dapat menurunkan tingkat kortisol pada post partum. Hal ini dapat merangsang produksi hormon prolaktin yang mempengaruhi jumlah ASI [12]. Dengan melakukan hypnopressure yang merupakan gabungan dari teknik hipnoterapi dan akupresur pada titik ST15,ST 16 ,ST 18, CV 17, SP 18, SI 1 dan ST 36 dapat merangsang produksi ASI. Area titik akupresur sebagaian besarsberpusat pada area payudara tepatnya satu titik di atas putting susu, sejajar putting dan di bawah putting, namun ada 1 titik berada di area leher dan 1 titik berada pada area lutut kaki. Intervensi hypnopressure ini memberikan rangsangan pada titik titik meridian untuk memberikan fungsi kerja maksimal terhadap organ target tepatnya di payudara [15].

Hasil penelitian ini sejalan dengan hasil penelitian Masruroh N (2017) menunjukkan bahwa hypnolactation pada ibu menyusui dapat meningkatkan pengeluaran kolostrum pada ibu primipara [18]. Didukung oleh Yu J, 2019 yang menyatakan hipnoterapi itu meningkatkan kenyamanan hingga $62 \%$ pada setiap tindakan dan Bryant RA menyatakan bahwa hipnoterapi dapat meningkatkan hormon oksitosinyang memberikan efek pengeluaran ASI yang lebih cepat serta meningkatkan kenyamanan di dalam tubuh sebesar 56\% [12,19].

Namun, hypnopressure memberikan efek sedatif dan relaksasi yang mengubah gelombang otak beta menjadi teta atau gamma (kondisi bawah sadar).Pada saat gelombang otak teta atau gamma, otak menghasilkan hormon serotonin, endorfin dan meningkatkan aktivitas saraf parasimpatik pada tubuh menjadi lebih nyaman dan meningkatkan kepercayaan diri melalui sugesti yang diberikan ketika melakukan hypnopressure [19].Menurut Bryant Brckway (2013)hypnopressure dapat merangsang oksitosin dalam tubuh, yang mengarah pada berkurangnya kecemasan tentang sosial situasi, perilaku dan peningkatan kepercayaan diri. Selain itu, pada saat 
hypnopressure, tubuh diperbaiki melalui sinyal kognitif yang dikirim ke otak untuk menutup pintu mekanisme rasa sakit di sistem pusat neuron [20,21].

Penelitian Sari (2017) menyatakan bahwa intervensi kombinasi hypnobreastfeeding mampu meningkatkan produksi ASI 2,5 kali lipat dibandingkan tidak diberikan intervensi [22]. Apabila intervensihypnobreastfeeding tidak berproses dengan baik maka terapi akupresur dapat membantu melalui cara kerja akupresur. Akupresur mampu merangsang serabut saraf $A \beta, A \delta$, dan $\mathrm{C}$, pada tingkat segmental merangsang sekresi opioid endogen dan serotonin, sehingga menghalangi proses rasa sakit dan mengaktifkan kembali fungsi organ dari masing-masing titik meridian terstimulasi untuk menghasilkan energi yang cukup [16].

Setelah intervensi, skor kepercayaan diri menyusui semakin meningkat dan sangat yakin untuk dapat menyusui bayinya hingga 6 bulan secara eksklusif. Temuan ini konsisten dengan teori efikasi diri menyusui [16] dan menunjukkan bahwa pencapaian kinerja langsung dan respons fisiologis merupakan sumber informasi keefektifan yang kuat dan memengaruhi persepsi kemampuan ibu untuk menyusui.Hasil dari penelitian ini mendukung temuan Dennis dan Faux, yang juga mengidentifikasi hubungan yang signifikan antara self-efficacy menyusui pada periode postpartum langsung dan hasil menyusui pada 6 minggu postpartum [24].

Penelitian ini juga mampu meningkatkan kepercayaan diri menyusui karena adanya kombinasi intervensi dari dua metode yaitu hipnoterapi dan akupresur secara bergantian yang memiliki mekanisme kerja yang sama untuk produksi ASI. Responden yang dilakukan akupresur akan merasa nyaman karena ketika dilakukan stimulasi pada titik ST15,ST 16 ,ST 18, CV 17, SP 18, SI 1 dan ST 36 akan meningkatkan hormon serotonin dan dopamine dan menurunkan norepineprin serta kortisol [17,24] Akibat penurunan norepineprin dan kortisol, ibu merasa tenang dan meningkatkatkan pengeluaran ASI. Beberapa penelitian menunjukkan bahwa akupresur memiliki efek analgesik degan melepaskan peptide sehingga mengurangi aktivitas simpatoadrenal yang akan aktif ketika dalam kondisi stress [16].

Asumsi peneliti bahwa faktor psikologi pada masa post partum akan dapat mempengaruhi produksi dan keyakinan dalam pemberian ASI. Dengan metode yang diberikan pada penelitian ini, peneliti dapat mencegah perubahan psikologi yang buruk seperti tidak yakin memiliki ASI yang cukup, nyeri saat menyusui, payudara bengkak dengan memberikan afirmasi positif pada saat melakukan hypnopressure sehingga ibu meyakini dirinya mampu memberikan ASI, menghasilkan ASI yang cukup bagi bayinya. Setelah hypnosis maka ibu akan mendapat intervensi akupresur. Stimulasi akupresur menyebabkan perubahan fisiologi lokal pada tubuh guna menghasilkan keseimbangan tubuh dimana area payudara yang dilakukan stimulasi akan meningkatkan otot-otot payudara bekerja lebih cepat sehingga aliran ASI lebih cepat keluar. Peneliti berasumsi bahwa hypnopressure mempengaruhi keyakinan ibu berupa fokus perhatian akan menyusui bayinya dengan teratur dan dapat mengurangi efek stress serta mempengaruhi aksi hormon ASI (prolaktin dan oksitosin) di dalam tubuhnya.

\section{Kesimpulan}

Hypnopressure mampu meningkatkan produksi ASI dan kepercayaan diri menyusui sehingga intervensi ini dapat dipertimbangkan untuk diberikan kepada ibu nifas dan menyusui dari awal kelahiran untuk dapat mensukseskan pemberian ASI eksklusif dengan kepercayaan diri yang tinggi.Hypnopressure juga dapat diaplikasikan dalam praktik Asuhan Kebidanan di perkuliahan dan di masyarakat dengan membantu para ibu nifas dalam melakukan hypnopressure.

\section{Ucapan Terima Kasih}

Peneliti mengucapkan terimakasih kepada Kementerian Pendidikan dan Kebudayaan (KEMENDIKBUD), kepada Lembaga Layanan Pendidikan Tinggi Wilayah I (LLDIKTI) dan Klinik Dini Lubuk Pakam Kabupaten Deli Serdang. Dukungan dari semua pihak, penelitian ini dapat terlaksana dan selesai dengan tepat waktu. 


\section{Referensi}

[1] Liu XH. Research advances in breastfeeding. Zhongguo Dang Dai Er Ke Za Zhi. 18:921-5. 2016.

[2] UNICEF. Child Info: Monitoring The Situation Of Children And Women. 2014. Statistics by area/water and sanitation. 2016.

[3] Victora CG, Bahl R, Barros AJD, França GVA, Horton S, Krasevec J, Murch S, Sankar MJ, Walker N, Rollins NC. Breastfeeding in the $21^{\text {st }}$ century: epidemiology, mechanisms, and lifelong effect. Lancet; 387(10017):475-90. 2016.

[4] Guo S, Fu X, Scherpbier RW, Wang Y, Zhou H, Wang X, et al. Breastfeeding rates in central and western China in 2010: implications for child and population health. Bull World Health Organ. 91:322-31. 2013.

[5] Otsuka, K., Taguri, M. Effectiveness of a Breastfeeding Self-efficacy Intervention : DoHospital Practices Make a Difference?. 296-306. 2014.

[6] $\mathrm{Ku}, \mathrm{C}$., Chow, S. Factors influencing the practice of exclusive breastfeeding among Hongkong Chinese women: a quistionnaire survey. J Clin Nurs. 19(17-18), 2434-45. 2010.

[7] Christian LM. Phsyconeuroimuno-logy in pregnancy: immune pathways linking stress with maternal health, adverse birth outcomes, and fetal development. 2012.

[8] Coussons ME. The Psychoneuro-immunology of Stress in Pregnancy. Association For Psycological Science 21(5): 323-328. 2012.

[9] Dib S, Rougeaux E, Vazquez-Vazquez A, Wells JCK, Fewtrell M. Maternal mental health and coping during the COVID-19 lockdown in the UK: data from the COVID-19 New Mum Study. Int J Gynaecol Obstet. 151:407-14. 2020.

[10] Guvenc G, Yesilcinar I, Ozkececi F, Oksuz E, Ozkececi CF,Konukbay D, et al. Anxiety, depression, and knowledge level in postpartum women during the COVID-19 pandemic. Perspect Psychiatr Care. 2020.

[11] Kurth E, Kennedy HP, Spichiger E, Hösli I, Zemp Stutz E. Crying babies, tired mothers: what do we know? A systematic review. Midwifery. 27(2):187-94. 2011.

[12] Yu J, Wells J, Wei Z, Fewtrell M. Randomized trial comparing the physiological and psychological effects of different relaxation interventions in Chinese women breastfeeding their healthy term infant. Breastfeed Med. 14:33-8. 2019.

[13] Innes KE, Selfe TK, Khalsa DS, Kandati S. Effects of meditation versus music listening on perceived stress, mood, sleep, and quality of life in adults with early memory loss: a pilot randomized controlled Trial. J Alzheimer's Dis. 52(4):1277-98. 2016.

[14] Henshaw, E. J., Fried, R., Siskind, E., Newhouse, L., \& Cooper, M..Breastfeeding selfefficacy, mood, and breastfeeding outcomes among primiparous women.Journal of Human Lactation, 31(3), 511- 518.https://doi.org/10.1177/0890334415579 654. 2015.

[15] Esfahani, Mitra Savabi; Soonghe, Shoreh Berenji; Valiani, Mahboubeh; Ehsanpour, S. Effect of acupressure on milk volume of breastfeeding mothers referring to selected health care centers in Tehran. Iranian Journal of Nursing and Midwifery Research, 20(1), 7-11. 2015.

[16] Mehta, P., Dhapte, V., Kadam, S., \& Dhapte, V. Contemporary acupressure therapy: Adroit cure for painless recovery of therapeutic ailments. Journal of traditional and complementary medicine, 2017.7(2), 251-263. 2017. 